\title{
POLITYKA
}

\section{Grzegorz Wroński}

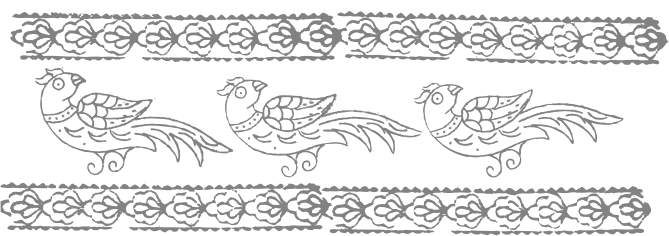

\section{MOCARSTWOWOŚĆ CHIN - PRZEGLĄD ATRYBUTÓW MIĘDZYNARODOWEJ POZYCJI WE WSPÓŁCZESNYM ŚWIECIE}

Wzrost znaczenia Chin, zwłaszcza w okresie ostatnich blisko 30 lat, uczynił kwestię mocarstwowości chińskiej istotną częścią dyskursu politycznego, gospodarczego, militarnego oraz kulturowego na temat obecnych i przyszłych losów, a także kierunków rozwoju świata. Nie sposób przejść do porządku dziennego wobec Chin, wyłaniających się z coraz większym potencjałem wpływów i rosnącym zakresem oddziaływania na wspólnotę międzynarodową. Wzmożona obecność Państwa Środka jest trudnym do zakwestionowania faktem naszej rzeczywistości. Zdecydowanie nie jest li tylko przedmiotem teoretycznych analiz naukowych lub częścią dyskusji i prognoz, prowadzonych przez specjalistyczne gremia, lecz elementem codziennego życia wielu mieszkańców naszego globu.

We współczesnym świecie narastającej współzależności i globalizacji nieustannie stykamy się, w sposób bardziej czy mniej uświadomiony, z mniejszą lub większą częścią chińskiej obecności. Nawet przeciętny członek naszego społeczeństwa musi nieraz zauważyć, a może go to nawet zaniepokoić, lub co najmniej zaciekawić, w jak wysokim stopniu jesteśmy konsumentami chińskich produktów. Nie trzeba więc posiadać wiedzy na temat znaczenia Chin w systemie naczyń połączonych gospodarki światowej, ani umieć naukowo ocenić pojawienie się alternatywnej siły politycznej w porządku międzynarodowym, aby dojść do konkluzji, że Chiny są ważne.

Nie powinniśmy jednak poprzestawać na intuicyjnej i powierzchownej percepcji owego, tak istotnego dla współczesnej rzeczywistości międzynarodowej, zjawiska. W tym celu dokonamy krytycznego przeglądu podstawowych atrybutów chińskiej mocarstwowości w wymiarze demograficznym, geopolitycznym, gospodarczym, militarnym i politycznym. Analiza wybranych aspektów pozycji międzynarodowej Chin 
ma posłużyć odpowiedzi na pytanie: czy rzeczywiście Chiny są mocarstwem i jaki charakter ma ich mocarstwowość.

Pozycja państwa w systemie międzynarodowym jest jednym z głównych czynników decydujących o możliwości osiąnnięcia statusu mocarstwowego. Jest ona zwykle utożsamiana z siłą lub potęgą państwa, określaną przez potencjał gospodarczy, polityczny i militarny ${ }^{1}$. W nurcie klasycznego realizmu potęga ta oznacza $z$ dolność wymuszania zachowań jednostek lub zbiorowości w pożadanym kierunku droga perswazji, przymusu czy zakazów i nakazów ${ }^{2}$. Według K. Holstiego pozycja państwa jest pochodnq roli deklarowanej przez decydentów i roli przypisywanej przez środowisko międzynarodowe ${ }^{3}$. W ujęciu Z. J. Pietrasia pozycja państwa jest zjawiskiem istniejacym obiektywnie, podczas gdy jego rola stanowi połaczenie elementów obiektywnych ze świadomościowymi ${ }^{4}$. Takie podejście kładzie nacisk na bezpośrednią zależność między kształtowaniem się zespołu ról odgrywanych przez państwo w środowisku międzynarodowym, a pozycją państwa wyrażaną przez obiektywnie istniejące atrybuty kondycji państwa.

W obu stanowiskach uwidacznia się podstawowa rozbieżność między rolami deklarowanymi przez same państwa lub przypisywanymi im przez środowisko międzynarodowe, a rolami bazującymi na obiektywnych podstawach, czyli poddających się wymiernej i bezstronnej ocenie. Czy samoświadomość lub uświadamianie przez innych uczestników posiadania wyjątkowej pozycji, wbrew lub mimo braku materialnych i wymiernych podstaw potęgi, może być podstawą uznania posiadania statusu mocarstwa? Bez wątpienia przypadek mocarstwowości ChRL może być przykładem braku jednoznacznej odpowiedzi na to pytanie.

Należy podkreślić, że pozycja państwa jako zjawisko istniejace obiektywnie nie jest oczywiście niezmienna i wymagałaby wsparcia ocen, dotyczących takiej pozycji, na obiektywnych jej wyznacznikach. Wartości poszczególnych parametrów pozycji ulegają ciagłej zmianie i nie mogą być absolutyzowane. Nawet maksymalna wartość pojedynczego atrybutu w danej chwili nie gwarantuje ogólnej pozycji dominującej państwa, a tym bardziej jej utrzymania w dłuższym okresie. Dlatego poszczególne atrybuty pozycji państwa powinny być mierzone w odniesieniu do analogicznych parametrów innych uczestników systemu międzynarodowego. Uznaje się, że przy określaniu pozycji państwa należy dokonywać pomiaru w powiazaniu z pozycja innych państw i przy założeniu nieistnienia czynników trwale ja kształtujacych ${ }^{5}$. Budowanie

${ }^{1}$ Por. uwagi na temat triadyczności potęgi oraz synonimicznego traktowania potęgi, mocarstwowości i potencjału: Mirosław Sułek, Podstawy potęgonomii i potęgometrii, Wyższa Szkoła Ekonomii i Administracji w Kielcach, Kielce 2001, s. 32.

${ }_{2}$ Za: Teresa Łoś-Nowak, Stosunki międzynarodowe. Teorie-systemy-uczestnicy, Uniwersytet Wroclawski, Wrocław 2000, s. 145.

${ }^{3}$ Tamże, s. 146.

${ }^{4}$ Ziemowit J. Pietraś, Międzynarodowa rola Chin, Wyd. Uniwersytetu Marii Curie-Skłodowskiej, Lublin 1990, s. 29.

5 Teresa Łoś-Nowak, cyt. wyd., s. 147. 
statusu mocarstwowego w oparciu o pewne przejawy pozycji państwa może być zawodne - pożądanym jest więc ocena jej parametrów przez pryzmat wplywów państw we wzajemnych stosunkach ${ }^{6}$. Dlatego badanie międzynarodowej pozycji państw jest zadaniem złożonym i niejednoznacznym.

\section{Pozycja demograficzna}

Za jeden z niewielu obiektywnych i niepodważalnych atrybutów mocarstwowej pozycji Chin należy uznać potencjał demograficzny. Niewątpliwie liczebność 1,321 mld ${ }^{7}$ mieszkańców, powodująca, że co piąty mieszkaniec globu to Chińczyk, predestynuje Chiny do zajmowania specjalnej pozycji pod tym względem. Historycznie Chiny zawsze były najludniejszym państwem. Zgodnie z wieloma prognozami, 20\% udział Chin w światowej populacji nie powinien zostać zagrożony w ciagu najbliższych dziesięcioleci przez drugiego miliardowego kolosa ludnościowego jakim są Indie, liczące obecnie 1,129 mld mieszkańców (17\% populacji światowej). Zgodnie jednak z pewnymi prognozami Chiny mogą stracić swój prymat na rzecz Indii około roku $2035^{8}$.

Sama liczba ludności, mimo że bardzo imponująca, nie decyduje o charakterze potencjału demograficznego. Chiny dysponują raczej niskiej jakości zasobem ludnościowym, głównie ze względu na nierównowagę struktury, poziom edukacji i skolaryzacji, nierównomierność rozmieszczenia i składu narodowościowego. Na etapie początkowym reform taki potencjał ludzki był nawet korzystny, gdyż gospodarkę chińską oparto na specjalizacji w produkcji pracochłonnej. Liczyła się więc ilość dostępnych i tanich pracowników, a nie ich jakość. Wraz z postępującym rozwojem, a nade wszystko mając na uwadze mocarstwowe aspiracje, wymagania pod tym względem będą nieporównywalnie rosły.

Nierównomierność zasiedlenia terytorium jest dla Chin bardzo charakterystyczna. Poza ograniczeniami wynikającymi ze środowiska geograficznego (niesprzyjające tereny pustynne i górskie, brak wody i żyznych gleb), reformy gospodarcze przyczyniły się do dalszego pogłębiania się tego zjawiska. Ludność koncentruje się tam, gdzie gospodarka rozwijała się najszybciej, czyli na wschodzie kraju, a zwłaszcza w prowincjach nadmorskich. Już w 1982 r. w części wschodniej kraju, zajmującej $42 \%$ powierzchni, zamieszkiwało ponad $93 \%$ populacji ${ }^{9}$. Rodzi to poważny problem z równomiernym rozwojem gospodarczym Chin. Przeciwdziałanie niedorozwojowi

${ }^{6}$ Tamże, s. 147.

7 CIA World Factbook 2007.

${ }^{8}$ Por. Nancy E. Riley, China's population: New trends and challenges, "Population Bulletin", VI 2004, s. 1.

9 Por. Andrzej Maryański i Andrzej Halimarski, Chiny, Państwowe Wydawnictwo Naukowe, Warszawa 1990, s. 51. 
regionów wewnętrznych i zachodnich w ostatnich latach staje się istotnym zadaniem chińskiej polityki gospodarczej. W 2000 r. ogłoszono w tym celu politykę ,,wielkiego rozwoju zachodu”, zwaną również polityką „marszu na zachód”"10.

Charakterystycznym zjawiskiem modernizujących się Chin są migracje ludności, głównie z terenów wiejskich do miast. Obok stałego zwiększania liczby ich mieszkańców i zaliczania do miast nowych centrów, występowały migracje okresowe. Ocenia się, że w połowie lat 90 . w procesie tym uczestniczyło od 30 do 100 mln Chińczyków. Jest to migracja szczególna, gdyż ludzie przenoszą się za praca, a potem większość powraca do swoich rodzinnych stron. Zjawisko to staje się poważnym wyzwaniem dla systemu ochrony zdrowia, zatrudnienia miejskiego, bezpieczeństwa publicznego, szkolnictwa, porządku fiskalnego oraz rolnictwa ${ }^{11}$.

Migracje należałoby również postrzegać w kategoriach pogłębiającej się luki między bogatymi i biednymi. Zanim nie zaczęły się reformy i Deng Xiaoping rzucił hasło „bogaćcie się”, Chiny należały do najbiedniejszych krajów. W okresie od 1978 r. do połowy lat 90., dochód per capita w miastach potroił się, a na terenach wiejskich wzrósł czterokrotnie ${ }^{12}$. Wzrost jest imponujący, lecz wciąż istnieje poważna różnica między poziomem rozwoju i dobrobytu w miastach oraz na wsi, a także analogicznie w regionach nadbrzeżnych i centralnych. Średni dochód mieszkańca miasta w 2004 r. to 10,493 yuany rocznie, na wsi zaś ponad trzy razy mniej - 3,255 yuanów ${ }^{13}$.

Z chwilą, kiedy zjawisko to stało się niebezpieczne dla stabilności rządów w Pekinie, za sprawą narastającego niezadowolenia społecznego ogłoszono w 2006 r. politykę tzw. nowej socjalistycznej wsi (new socialist countryside). Zakłada ona zwiększenie wydatków na rolnictwo i infrastrukturę wiejską oraz wsparcie socjalne dla 800-milionowej rzeszy mieszkańców wsi. Nieco wcześniej zniesiono podatek rolny, którego historia sięga ponad 2,500 lat wstecz ${ }^{14}$.

Konsekwentna realizacja polityki planowania rodziny, zakładająca m.in. model rodziny „2+1” w mieście i dopuszczalność „2+2” na wsi, pod względem ograniczenia przyrostu ludności okazała się skuteczna, ale zapoczątkowała rozmaite inne niekorzystne zmiany ${ }^{15}$. Przyrost naturalny został opanowany i jego wskaźnik wynosi obecnie $0,6 \%$, czyli ponad 8 mln ludzi rocznie ${ }^{16}$. Pojawiło się jednak nowe wyzwanie, jakim jest dysproporcja w strukturze płci. Na każde 100 dziewczynek w wieku

${ }^{10}$ Under the thumb. China's Far West, "Economist", 1.12.2005.

${ }^{11}$ Por. N.E. Riley, cyt. wyd., s. 13.

12 Tamże.

${ }^{13}$ Facts and figures: China's major achievements in 2005, "People's Daily", 17.03.2006.

${ }^{14}$ China aims to let rural poor share new wealth, "International Herald Tribune", 5.03.2006; China's drive to build socialist new countryside, "People's Daily", 5.03.2006.

15 Por. Karin Tomala, Planowanie rodziny warunkiem modernizacji kraju, w: Karin Tomala (red.), Chiny: Przemiany państwa i społeczeństwa w okresie reform 1978-2000, Instytut Studiów Politycznych PAN i Wydawnictwo Trio, Warszawa 2001.

${ }^{16}$ CIA World Factbook 2007. 
1-4 lat przypada ponad 120 chłopców ${ }^{17}$. Podobnie niepokojącym zjawiskiem jest starzenie się społeczeństwa, rodzące poważne skutki społeczne. Zdaniem N. Eberstadta tempo tego procesu jest zaskakujące. Obecnie mediana wieku w Chinach wynosi 33 lata, w USA - 36, a w Japonii - 43 lata. Według prognoz już w 2025 r. może ona w Chinach wynieść 39 lat. Udział mieszkańców Chin powyżej 60. roku życia wyniósł w 2000 r. ponad $10 \%$, a w 2050 może stanowić aż $27 \%{ }^{18}$. O powadze problemu świadczyć może opinia, że Japonia stała się bogata, nim się zestarzała, a Chiny zrobiq to na odwrót ${ }^{19}$.

Rozmiar chińskiej populacji budzi poważne niepokoje w kraju i za granica. Dotyczą one możliwości wyżywienia i zaopatrzenia w wodę tak wielkiej liczby ludności. Chiny dysponują mniej niż 10\% światowych zasobów ziemi uprawnej, muszą jednak wyżywić $20 \%$ ludzkości. Zmniejszający się areał ziemi uprawnej, malejąca podaż wody w połączeniu z rosnącą liczbą konsumentów i ich wymagań żywieniowych, prowadzi nie tylko do utraty pewnego bezpiecznego poziomu samowystarczalności żywnościowej, lecz rodzi pytania, czy świat będzie w stanie zaspokoić popyt z ich strony. Już w połowie lat 90 . Chiny z tradycyjnego eksportera zbóż stały się największym - po Japonii - importerem; podobnie w przypadku mięsa stały się głównym światowym konsumentem. Według L.R. Browna, jeśli plan stabilizowania przyrostu naturalnego nie zostanie utrzymany oraz nie rozpocznie się odpowiednia polityka pobudzania rozwoju chińskiego rolnictwa i promowania bardziej oszczędnego gospodarowania posiadanymi zasobami naturalnymi, problem wyżywienia Chin w skrajnym przypadku może stanowić dla świata bardzo poważne wyzwanie ${ }^{20}$.

Szczęśliwie czarny scenariusz potrzeby dożywiania Chin na razie się nie spełnia. Należy nawet podkreślić, że w 2006 r. World Food Program zakończył udzielanie Chinom pomocy żywnościowej. Świadczy to o uzyskaniu przez ten kraj zdolności do zapewnienia swojemu społeczeństwu bezpieczeństwa żywnościowego. Przy okazji tego wydarzenia Chiny ogłosiły, że od chwili zapoczątkowania reform liczba ludności ubogiej, pozbawionej odpowiedniego wyżywienia i ubioru, zmniejszyła się z 250 do $26,1 \mathrm{mln}^{21}$.

Pod względem struktury narodowościowej Chiny, wydawać by się mogło, nie powinny mieć poważnych problemów. Zaledwie $9 \%$ stanowią mniejszości narodowe, na które składa się aż 56 narodowości. Dominacja Hanów nie powinna być więc problemem. A jednak w pewnych obszarach, zwłaszcza w Xinjiangu i Tybecie, występują bardzo silne tendencje odśrodkowe. Wśród samych Hanów również występują problemy z identyfikacją etniczną, wiążącą się z odmiennościami językowymi.

${ }^{17}$ Por. Nicholas Eberstadt, Power and population in Asia, "Policy Review”, II 2004, s. 15.

18 Por. N.E. Riley, cyt. wyd., s. 9.

19 Por. N. Eberstadt, cyt. wyd., s. 9.

${ }^{20}$ Por. Lester R. Brown, Who will feed China: Wake-up call for a small planet, Worldwatch Institute, Washington 1995.

${ }^{21}$ A solid answer to 'Who will feed China', "People's Daily", 4.01.2006. 
Analizując potencjał demograficzny jako wyznacznik chińskiej mocarstwowości należy przyznać, że jego wymiar jest głównie ilościowy ${ }^{22}$. W aspekcie jakościowym potencjał ludzki Chin jest bowiem stosunkowo niski, a w rezultacie tak duża liczebność stanowi wręcz obciążenie i jest obarczona bardzo poważnym ryzykiem przekształcenia się w realne zagrożenie dla samych Chin. Analizy pozycji demograficznej Chin nie można jednak ograniczać jedynie do mieszkańców terytorium ChRL. Uwzględnić należy pozytywny wpływ, jaki wywarło przyłączenie w końcu lat 90 ., niezbyt licznej, lecz stojącej na znacznie wyższym poziomie cywilizacyjnym ludności Hongkongu i Makau. Tym większym wydarzeniem będzie ewentualne zjednoczenie Tajwanu z Chinami. Nie należy również zapominać o ponad 50-milionowej diasporze chińskiej (huaqiao), która ma bardzo istotny udział w rozwoju gospodarki Chin kontynentalnych.

Przy okazji omawiania aspektu demograficznego, choć może dotyczyć to także wielu innych wymiarów, warto przytoczyć opinię Zheng Bijiana o istnieniu w przypadku Chin szczególnego paradoksu „dzielenia i mnożenia”23. Dotyczy on sytuacji, kiedy duża zagregowana wartość, dzielona między ogromną populację, staje się wielkością bardzo małą. Analogicznie małe jednostkowe problemy, mnożone przez liczbę ludności, urastają do niewiarygodnych rozmiarów. W tym ujęciu, według D. Lamptona, uprawnionym może być stwierdzenie, że Chiny mogą być słabe i silne jednocześnie. Populacja o rozmiarze 1,3 mld, z klasą średnią liczącą prawdopodobnie $250 \mathrm{mln}$, może jednocześnie pełnić rolę ogromnej siły konkurencyjnej, napędzającej motor światowej gospodarki, ale może także stać się potężnym wyzwaniem humanitarnym i rozwojowym dla świata w przypadku czarnego scenariusza: załamania się $\mathrm{Chin}^{24}$.

\section{Pozycja geopolityczna}

Kolejnym atrybutem mocarstwowości Chin jest ich ogromne terytorium. Obszar liczący ponad 9,598 tys. $\mathrm{km}^{2}$ daje im trzecie miejsce na świecie, za Rosją i tuż za Kanadą. Chiny dysponują terytorium niespełna $9 \%$ mniejszym od powierzchni całej Europy, rozumianej w sensie geograficznym. Mimo tak dużego obszaru nie podzieliły one losów Europy, wysoce zróżnicowanej wewnętrznie, i zachowały od starożytności jedność polityczna, mimo okresowych załamań tworząc zwarte unitarne państwo ${ }^{25}$.

${ }^{22}$ Por. Krzysztof Iwańczuk, Pozycja demograficzna i geopolityczna ChRL, w: Krzysztof Iwańczuk, Agata Ziętek (red.), Chiny w stosunkach międzynarodowych, Wydawnictwo UMCS, Lublin 2003, s. 54-56.

${ }^{23}$ David M. Lampton, Paradigm lost: The demise of 'weak China', "The National Interest", 2005 nr 81, s. 74.

${ }^{24}$ Tamże, s. 74.

${ }_{25}$ Por. Leszek Moczulski, Geopolityka. Potęga w czasie i przestrzeni, Dom Wydawniczy Bellona, Warszawa 1999, s. 102-103. 
Struktura geofizyczna chińskiego terytorium nie jest zbyt korzystna. W ukształtowaniu terenu dominują góry (33\%), wyżyny (36\%) i kotliny (19\%). Niziny stanowią tylko $12 \%$ i są one jednocześnie głównymi terenami koncentracji ludności oraz życia gospodarczego ${ }^{26}$.

Ogrom terytorium i stosunkowo obfite zasoby surowców naturalnych powodują jednak nader nierównomierne zasiedlenie i wykorzystanie terenów. Staje się to ogromnym wyzwaniem dla rozbudowywanej i wciąż nie w pełni rozwiniętej sieci transportu kolejowego, rzecznego i drogowego. Dominujące tereny górzyste i pustynne powodują, że większość ludności koncentruje się zwłaszcza w pasie nadmorskim, co prowadzi do poważnych dysproporcji w rozwoju Chin wschodnich i zachodnich. Jednocześnie szybki rozwój gospodarczy stawia coraz wyższe i trudne do sprostania wymagania zdolnościom eksploatacyjnym i zasobom surowcowym.

Pod względem położenia geopolitycznego Chiny niewątpliwie zajmują bardzo uprzywilejowane miejsce. Obejmując wschodnią i centralną część kontynentu azjatyckiego, przy szerokim dostępie do Oceanu Spokojnego, są w stanie kontrolować i wpływać na rozwój sytuacji nie tylko względem swoich najbliższych sąsiadów, lecz całych regionów Azji, zwłaszcza Azji Centralnej, Wschodniej i PołudniowoWschodniej.

W aspekcie strategicznym przylegające do Chin Morza Południowo- i Wschodniochińskie posiadają szczególne znaczenie strategiczne. Przebiegają przez nie najważniejsze szlaki morskie, łączące Azję Północno-Wschodnią z Oceanem Indyjskim. Ocenia się, że skala odbywającego się tu transportu morskiego przewyższa dwukrotnie tranzyt w Kanale Sueskim i trzykrotnie w Kanale Panamskim. Około 15\% handlu światowego przechodzi przez te szlaki, a japońskiego handlu zagranicznego aż $39 \%{ }^{27}$. Dlatego bliskość tych akwenów, wysuwanie roszczeń terytorialnych do ich części oraz potencjalna możliwość blokowania szlaków dostaw głównego regionalnego konkurenta, jakim jest Japonia, zwiększa istotnie geopolityczne walory chińskiego położenia.

Chiny to przede wszystkim jednak mocarstwo lądowe. Posiadają, co prawda, dość imponujące osiagnięcia w eksploracji morskiej, ale miały one miejsce przed ponad pięcioma wiekami ${ }^{28}$. Z perspektywy Chin jako mocarstwa lądowego strategiczne położenie kraju przejawia się przede wszystkim w bezpośredniej bliskości bogatych złóż surowców energetycznych w Azji Centralnej. Fakt ten nie tylko może służyć zaspokajaniu własnych potrzeb energetycznych, lecz również podwyższaniu strategicznej wartości Chin jako państwa tranzytowego, łączącego Azję Centralną z głównymi go-

${ }^{26}$ Por. A. Maryański i A. Halimarski, cyt. wyd., s. 14.

27 Por. Edward Haliżak, Spór o archipelagi na Morzu Poludniowochińskim - znaczenie dla międzynarodowego prawa morza i bezpieczeństwa w regionie, w: Edward Haliżak, Roman Kuźniar (red), Prawo, instytucje i polityka w procesie globalizacji, „Scholar”, Warszawa 2003, s. 184-185.

${ }_{28}$ Por. Menzies Gavin, 1421 - rok, w którym Chińczycy odkryli Amerykę i optynęli świat, Amber, Warszawa 2002. 
spodarkami Azji Północno-Wschodniej - Japonią i Koreą. Jedwabny Szlak może zostać w ten sposób reaktywowany w postaci „szlaku naftowego" ${ }^{29}$.

Bardziej dalekosiężnym planem strategicznym jest uzyskanie za pośrednictwem Azji Centralnej bezpośredniego dostępu do zasobów bliskowschodnich ${ }^{30}$. Na podobnych zasadach sąsiedztwo Rosji stwarza Chinom szansę uczestnictwa w eksploatacji nieprzebranych bogactw naturalnych Syberii ${ }^{31}$. Jednocześnie bliskość geograficzna najbardziej zapalnego pod względem bezpieczeństwa punktu Azji Wschodniej, podzielonego Półwyspu Koreańskiego ${ }^{32}$, przy zachowaniu specyficznych relacji z reżimem z Phenianu, czyni z Chin kluczowego uczestnika procesu stabilizowania i łagodzenia napięć związanych z tym kryzysem.

Strategiczne położenie Chin powoduje, że coraz bardziej angażują się one w sprawy swego regionu, a także są aktywniej obecne w najważniejszych regionalnych organizacjach i forach. Godnym szczególnego podkreślenia jest parcie Chin ku poradzieckim krajom Azji Centralnej, za pośrednictwem skonstruowanej wespół z Rosją Szanghajskiej Organizacji Współpracy (SCO), dialog z państwami Stowarzyszenia Narodów Azji Południowo-Wschodniej (ASEAN) w miejsce konfrontacji w związku ze sporami terytorialnymi o wyspy Morza Południowo-chińskiego ${ }^{33}$ oraz współpraca z innymi mocarstwami w stabilizowaniu sytuacji na Półwyspie Koreańskim ${ }^{34}$.

Tym samym Chiny wybijają się na centralną pozycję w szeroko rozumianym regionie Azji i Pacyfiku, a dzięki temu i świata, gdyż tworząca się tzw. Wspólnota Pacyfiku, zgodnie z przewidywaniami specjalistów, stanie się prawdopodobnie wkrótce - jak to określił Edward Haliżak - regionem, ku któremu zmierza punkt grawitacji wspótczesnego świata gospodarczo-politycznego ${ }^{35}$.

Charakter i typ geostrategicznej pozycji, w połączeniu z rosnącą rolą Chin jako mocarstwa, skłania ku refleksji na temat ewentualnej aktualności klasycznych teorii geopolitycznych. Koncepcja Heartlandu autorstwa H. Mackindera zakłada, że historia nowożytna to walka mocarstw lądowych i morskich. Predestynowana do panowania nad światem jest jednak potęga lądowa, znajdująca się w „sercu lądu”. Heartland

\footnotetext{
${ }^{29}$ Por. Carlo Jean, Geopolityka, Wydawnictwo Ossolińskich, Wrocław 2003, s. 327.

${ }^{30}$ Por. J. Peter Pham, Beijing's great game: Understanding Chinese strategy in Central Eurasia, “American Foreign Policy Interest”, 2006 nr 26, s. 58.

${ }_{31}$ Por. Stuart Harris, China 's regional policies: how much hegemony? "AAustralian Journal of International Affairs", $2005 \mathrm{nr}$ 4, s. 487.

32 Por. E. Haliżak, Regionalny „,kompleks bezpieczeństwa” w Azji Pólnocno-Wschodniej, „Żurawia Papers" (Instytut Stosunków Międzynarodowych UW, Warszawa), zeszyt 3, 2004, s. 148.

33 Por. William J. Dobson, M. Taylor Fravel, Red hegemon: China in the South China Sea, „Current History", IX 1997, s. 258-263.

${ }^{34}$ Por. E. Haliżak, Region Azji i Pacyfiku w polityce międzynarodowej, w: Krzysztof Gawlikowski (red.), Azja Wschodnia na przełomie XX i XXI wieku. Stosunki międzynardowe i gospodarcze, Wyd. Trio, Warszawa 2004, s. 179-185.

${ }_{35}$ E. Haliżak, Stosunki międzynarodowe w regionie Azji i Pacyfiku, cyt. wyd., nota wprowadzająca; por. Bruce Cumings, What is a Pacific Century - and how will we know when it begins?, "Current History", X 1994, s. 401-406.
} 
w różnych okresach uzyskiwał nieco odmienne interpretacje, zawsze jednak obejmował zwarty obszar euroazjatycki, złożony z terenów Rosji, Azji Centralnej i co najmniej części zachodnich Chin. Opanowanie Heartlandu miało zapewniać dominację nad „wyspą świata”, czyli kontynentem europejskim, afrykańskim i azjatyckim, a ta umożliwić panowanie nad całym światem ${ }^{36}$. Koncepcja owa została poddana krytyce przez N. J. Spykmana, jako przeceniająca znaczenie obszaru lądowego i niedoceniająca skutków braku odpowiedniej sieci transportu wewnętrznego i słabego dostępu z zewnątrz. W jej miejsce Spykman stworzył koncepcję obrzeża kontynentu, zwanego Rimland. Zasadnicze znaczenie strategiczne mają w niej nie centralne, lecz kresowe obszary Eurazji. Panowanie na obrzeżach, jako bufor między mocarstwami lądowymi i morskim, ma zapewnić dominację w świecie ${ }^{37}$.

Tezy obu szkół geopolitycznych mają bezpośredni związek z kwestią mocarstwowości Chin. Leżą one, częściowo lub w całości, zarówno w obrębie Heartlandu jak i Rimlandu. Powinny więc mieć szansę na osiągnięcie dominującej pozycji według każdej z nich z osobna, a być może nawet jako synergia obu. Tym bardziej, iż nie należy wspomnianych koncepcji uznawać za przestarzałe lub martwe. Można znaleźć dowody na to, że ich duch jest wciąż obecny w polityce międzynarodowej. Pewne inspiracje koncepcją Mackindera można chyba dostrzec w rywalizacji strategicznej USA, Rosji i Chin o wpływy w Azji Centralnej, która ze względu na bogate zasoby energetyczne mogłaby stać się zalążkiem „osi świata”. W USA można odnaleźć wpływ tez Spykmana m. in. w koncepcjach, traktujących priorytetowo przeciwdziałanie koalicji europejsko-rosyjskiej lub opartej o Chiny, które mogłyby zagrozić globalnej potędze USA ${ }^{38}$.

\section{Pozycja gospodarcza}

Wymiar gospodarczy jest ogólnie uznawany za najmocniejszy i najmniej dyskusyjny atrybut chińskiej mocarstwowości. Jest namacalnym i najbardziej rozpowszechnionym przejawem chińskich wpływów, tak szeroko obecnym w gospodarkach większości państw świata, że nagły brak dopływu produktów made in China mógłby skutkować poważnymi reperkusjami.

W opinii E. Haliżaka komponent ekonomiczny dla samych Chin jest najważniejszą przesłanką odzyskania mocarstwowej pozycji ${ }^{39}$. Za symptomatyczne uznaje on odwoływanie się Chińczyków do prac A. Maddisona, P. Kennedy'ego i S. P. Huntingtona ze względu na uznawanie przez nich Chin za mocarstwo światowe aż do

${ }^{36}$ Por. Józef Barbag, Geografia polityczna ogólna, PWN, Warszawa 1987, s. 12.

37 Por. Stanisław Otok, Geografia polityczna, Wyd. Naukowe PWN, Warszawa 2003, s. 14-15.

${ }^{38}$ Por. C. Jean, cyt. wyd., s. 82.

${ }^{39}$ E. Haliżak, Zmiana układu sił USA-Chiny a transformacja porzqdku międzynarodowego, „Żurawia Papers", zeszyt 7, 2005, s. 55. 
połowy XIX w. ${ }^{40}$. Jak wyliczano, do czasu dominacji Europy Chiny miały najwyższy, bo ponad 32\% udział w światowej produkcji przemysłowej, w stosunku do 5\% udziału Rosji, 3,8\% Japonii, 4\% Francji i 1,9\% Wielkiej Brytanii ${ }^{41}$. Odzyskanie utraconej pozycji gospodarczego mocarstwa, a nawet światowego lidera, stało się w okresie reform rozpoczętych w 1978 r. głównym celem strategicznym Pekinu. Polityka „czterech modernizacji” zakładała unowocześnienie przemysłu, rolnictwa, obrony narodowej i poziomu technologicznego, które umożliwiłyby szybki rozwój państwa i zbudowanie materialnych podstaw mocarstwowej pozycji.

Wypracowany na początku reform plan czterokrotnego zwiększenia dochodu narodowego do końca XX w. został zrealizowany w 1997 r. Początek XXI w. przyniósł kolejny cel: czterokrotne zwiększenie PKB z poziomu 2000 r. do 2020 r. Tempo modernizacji gospodarki, wzrostu gospodarczego i realizacji stawianych sobie celów rozwojowych może imponować. Należy w tym aspekcie podkreślić szczególny pragmatyzm Chińczyków, którzy traktując priorytetowo gospodarkę nie wahają się przed konstruowaniem karkołomnych koncepcji od „socjalizmu o chińskiej specyfice” do „socjalistycznej gospodarki rynkowej” i „trzech reprezentacji”, aby tylko utrzymać pewien ład polityczno-ideologiczny i kontynuować modernizację.

Trwający do dziś, czyli ponad ćwierć wieku, szybki i nieprzerwany wzrost gospodarczy w Chinach jest w historii bezprecedensowy. Trzeba jednak pamiętać, że zarówno poziom rozwoju, z którego reformy startowały, był szczególnie niski, oraz że wciąż chińska gospodarka wykazuje poważne braki i niebezpieczne zjawiska, mogące zagrozić jej dalszemu wzrostowi. W zależności od zastosowanego podejścia i użytych statystyk można wykazać, że Chiny to potęga ekonomiczna lub jeden z wielu zacofanych krajów rozwijających się. Według tradycyjnych wyliczeń PKB Chiny zajmują czwarte miejsce z udziałem 5,4\% w światowym $\mathrm{PKB}^{42}$. Wyprzedzają je USA, Japonia oraz Niemcy, te ostatnie z bardzo niewielką przewagą. Warto jednak zaznaczyć, że tempo wzrostu chińskiego udziału jest imponujące - jeszcze w 2003 r. zajmowały siódme miejsce ${ }^{43}$. Przy niższym nawet niż dotychczas tempie wzrostu rzędu 7-8\% rocznie, prognozuje się możliwość zrównania produktu krajowego Chin i USA do roku 2035.

Natomiast jeśli zastosować wskaźnik PPP, to jest wyliczać wartość PKB według realnej siły nabywczej waluty krajowej (co faworyzuje gospodarki słabiej sytuowane), ChRL plasuje się jako druga gospodarka świata z udziałem 15,3\%, tuż za USA z wynikiem $19,9 \%^{44}$. W tym układzie dystans Chin do gospodarki amerykańskiej był-

${ }^{40}$ Por. Samuel P. Huntington, Zderzenie cywilizacji i nowy ksztalt ładu światowego, Wyd. Muza, Warszawa 1997, s. 114; Angus Maddison, Chinese economic performance in the long run, OECD, Paris 1998.

${ }^{41}$ Por. Paul Kennedy, Mocarstwa świata: Narodziny, rozkwit, upadek, Książka i Wiedza, Warszawa 1995 , s. 154.

${ }^{42}$ Por. CIA World Factbook 2007, cyt. wyd.

${ }^{43}$ Por. CIA World Factbook 2003, cyt. wyd.

${ }^{44}$ Por. CIA World Factbook 2007, cyt. wyd. 
by nieporównanie mniejszy. Jest to już relacja 10 bln do 12,9 bln USD, a nie 2,5 bln do 13,2 bln USD w cenach stałych.

Kwestia, które miejsce zajmują Chiny w czołówce gospodarki świata, nie wydaje się jednak najistotniejsza, gdyż tak czy inaczej Chiny są bardzo ważnym jej uczestnikiem. Za najważniejszy argument na rzecz uznania gospodarczej potęgi Chin można chyba przyjąć utrzymywanie rekordowo długo imponującego wzrostu gospodarczego, oscylującego w granicach 10\%. Według danych Banku Światowego przeciętny wzrost w okresie 1978-95 wyniósł 9,4\% rocznie, a w okresie 1983-2003 wg OECD osiagnął 9,8\% ${ }^{45}$. W 2006 r. wyniósł $10,5 \%{ }^{46}$, a w pierwszym kwartale 2007 r. wzrósł do $11,1 \%{ }^{47}$. Jak dotychczas nie potwierdzają się zapowiedzi znacznego spowolnienia, powtarzane od lat. Aczkolwiek w długoterminowej perspektywie takie zjawisko może mieć miejsce, to jego skala nie musi być szczególnie alarmująca. Do 2015 r., według najbardziej optymistycznej prognozy Chińskiej Akademii Nauk Społecznych z roku 2000, wyhamowanie może jedynie obniżyć średnie tempo wzrostu do poziomu $8 \%$, zaś w prognozach najbardziej pesymistycznych (RAND) do $5 \%{ }^{48}$. Tym samym można uznać, że prawdopodobieństwo załamania rozwoju Chin jest raczej niewielkie.

Według RAND załamanie takie mogło by się wydarzyć przy zbiegu wielu czynników na raz, takich jak: a) bezrobocie, ubóstwo i niepokoje społeczne (spadek o $0,3-0,8 \%$ rocznie); b) rozwój korupcji $(0,5 \%)$; c) masowe epidemie (SARS, AIDS) $(1,8-2,2 \%)$; d) brak wody i wzrost zanieczyszczenia środowiska $(1,5-1,9 \%)$; e) wzrost cen i konsumpcji energii $(1,2-1,4 \%)$; f) słabość systemu finansowego i rosnące zadłużenie przedsiębiorstw państwowych $(0,5-1 \%)$; g) zmniejszenie napływu inwestycji zagranicznych $(0,6-1,6 \%)$; h) konflikty, w tym wokół kwestii Tajwanu $(1-1,3 \%)^{49}$. Utrzymanie wysokiego tempa rozwoju jest dla Chin szczególnie istotne, gdyż umożliwia nadrabianie zapóźnień w rozwoju i wzmacnianie międzynarodowej pozycji. Dla świata jest ono również pozytywnym zjawiskiem, oddalającym perspektywę czarnego scenariusza kryzysu w Chinach.

Spektakularnie prezentują się wskaźniki bezpośrednich inwestycji zagranicznych (FDI) w Chinach. Ich przyciaganie stało się celem wielu działań ChRL na arenie międzynarodowej. Skumulowana do 2002 r. wartość inwestycji w Chinach wyniosła ponad 500 mld USD, co stanowi ponad 8\% światowego udziału ${ }^{50}$ oraz daje Chinom miejsce lidera w świecie, dystansującego nawet USA. Rynek chiński w tym względzie jest is-

\footnotetext{
${ }^{45}$ Por. China's ascent: Can the Middle Kingdom meet its dreams?, "Global Economic Papers" Nr 133, Goldman Sachs, 2005.

${ }^{46}$ Por. CIA World Factbook 2007, cyt. wyd.

47 Por. David Barboza, Chinese economy soars at 11.1\% pace in first quarter, "International Herald Tribune", 19.04.2007.

${ }^{48}$ E. Haliżak, Zmiana uktadu sit USA-Chiny ..., cyt. wyd. s.69

${ }^{49}$ Por. Charles Wolf $\mathrm{i}$ in. Fault lines in China's economic terrain, RAND, 2003, roz. X, s. 7-8.

${ }^{50}$ Dane stat. dot. inwestycji w Chinach - UNCTAD: http://stats.unctad.org/fdi/eng/TableViewer/ wdsview/dispviewp.asp
} 
totnym konkurentem dla innych ,gospodarek wschodzących”, pochłaniając około 2/3 napływających do nich kapitałów ${ }^{51}$. Mocna pozycja Chin jako odbiorcy FDI opiera się przede wszystkim na stabilności polityczno-gospodarczej kraju, otwarciu na zagranicę oraz taniej sile roboczej, liczącej $700 \mathrm{mln}$ ludzi w wieku produkcyjnym ${ }^{52}$. FDI pełnią względem chińskiej mocarstwowości ważne funkcje. $Z$ jednej strony umożliwiają im dalszy rozwój, z drugiej czynią z Chin bardziej przewidywalnego uczestnika wspólnoty międzynarodowej, który musiałby dokonać poważnej kalkulacji zysków i strat, nim podejmie jakiekolwiek działania łamiące zasady wspólnoty i mogące pociagnąć za sobą utratę dopływu kapitału.

Pozostając największym odbiorcą i atrakcyjnym miejscem dla inwestycji zagranicznych, Chiny stopniowo zaczynają odgrywać rolę poważnego eksportera kapitału. Wpisuje się to w ogłoszoną w 2001 r. przez premiera Zhu Rongji strategię, wychodzenia na zewnątrz" (go out) i inwestowania poza granicami kraju ${ }^{53}$. W planie jest stworzenie grupy 20-30 przedsiębiorstw chińskich kontrolowanych przez państwo celem prowadzenia globalnej działalności ${ }^{54}$. Za E. Haliżakiem do motywów ekspansji chińskich przedsiębiorstw zaliczyć można: a) zabezpieczanie dostaw surowców i nośników energii; b) poprawę zarządzania i transfer know-how; c) zmniejszenie presji rewaluacyjnej na juana poprzez wywóz kapitału za granicę; d) unikanie barier eksportowych; i e) rosnącą konkurencję na rynku wewnętrznym ${ }^{55}$. Jeśli pamięta się, że takie działania wielkich chińskich firm są inspirowane i wspomagane przez państwo, nie powinno zaskakiwać, że będą one miały ogromny wpływ na pozycję i obecność Chin w świecie. Co może sobie bowiem pomyśleć przeciętny konsument, stawiając na biurku nowy komputer chińskiej marki Lenovo zamiast IBM?

Udział Chin w handlu międzynarodowym jest równie znaczący. 2006 r. przyniósł im 3. miejsce pod względem eksportu, z udziałem $7,8 \%$, oraz 3 . miejsce w rankingu importerów, przy $6,43 \%$ udziale ${ }^{56}$. Pod względem ogólnej wartości handlu zajmują również 3. miejsce z udziałem $7,1 \%$. Szybki awans w statystykach handlowych jest wynikiem wysokiego tempa liberalizacji wymiany gospodarczej z zagranica, a przede wszystkim efektem przyjęcia Chin do WTO w 2001 r. W aspekcie handlowym szczególnego znaczenia nabiera wzrost chińskiego importu. W opinii E. Haliżaka dzięki wyższej importochtonności Chiny zaczynaja w o wiele większym stopniu odgrywać, poprzez uruchamianie w innych państwach efektów mnożnikowych, rolę regionalnej lokomotywy wzrostu ${ }^{57}$. Z analizy struktury geograficznej chińskiego handlu zagranicznego wynika ważna prawidłowość: w handlu z państwami Zachodu Chiny osiagają

${ }^{5}$ Por. E. Haliżak, Pozycja ekonomiczna ChRL, w: K. Iwańczuk, A. Ziętek (red.), Chiny w stosunkach ..., cyt. wyd., s. 61-62.

52 Ibidem, s. 58

53 Por. Yongjin Zhang, China goes global, Foreign Policy Centre, London 2005, s. 9.

54 Por. E. Haliżak, Zmiana układu sit USA-Chiny..., cyt. wyd., s. 67.

55 Tamże, s. 67, za China business forecast report 2005.

56 Por. CIA World Factbook 2007, cyt. wyd.

57 Por. E. Haliżak, Zmiana układu sił USA-Chiny..., cyt. wyd., s. 58-59. 
nadwyżkę, natomiast w obrotach z państwami Azji Wschodniej, z uwzględnieniem Japonii, notują deficyt. Potwierdza to znaczenie Chin jako lokomotywy wzrostu gospodarczego innych państw oraz legitymizuje przywódczą rolę w regionie ${ }^{58}$.

Znamiennym jest, że jeśli ujmie się dane dotyczące ChRL i Hongkongu łącznie, to pod względem eksportu Chiny plasują się na miejscu lidera, wyprzedając USA aż o 4,5 pkt \%, zaś w imporcie awansują na 2. miejsce, wyprzedzając Niemcy o 1,6 pkt \%. W takim układzie ogólna wartość handlu zagranicznego awansowałaby zjednoczone Chiny na 2 . miejsce $\mathrm{z}$ udziałem mniejszym od amerykańskiego jedynie o $0,8 \mathrm{pkt} \%$.

Dzięki trwale utrzymującej się nadwyżce w obrotach handlowych oraz napływowi inwestycji zagranicznych, Chiny posiadają największe w świecie rezerwy walutowe, oceniane w 2006 r. na 1,034 bln USD. Nadwyżka jest równoważona m.in. przez bezpośrednie inwestycje za granicą oraz zakup zagranicznych obligacji. Ocenia się, że w posiadaniu Chin znajduje się około 300 mld USD w amerykańskich obligacjach skarbowych. To czyni z nich jedno z głównych źródeł finansowania amerykańskiego deficytu budżetowego ${ }^{59}$. Dostrzegając niebezpieczeństwa takiej sytuacji Ph. Segal stwierdził, że Chiny posiadły zdolność zniszczenia amerykańskiego rynku obligacji ${ }^{60}$.

Według E. Haliżaka kluczowa rola Chin w tym aspekcie przejawia się w ich wpływie na wysokość stóp procentowych w świecie i na ceny pieniądza. Dokonuje się on za pośrednictwem dwóch mechanizmów: a) tani eksport chiński zwiększa siłę nabywczą ludności, stymuluje konsumpcję i inwestycje, co w rezultacie podtrzymuje stan wysokiej koniunktury; b) zakupy zagranicznych obligacji rządowych obniżają koszty finansowania deficytu budżetowego USA ${ }^{61}$. W ocenach tygodnika „The Economist" od Chin zależy dziś coraz bardziej inflacja w świecie, rentowność obligacji, płace oraz ceny, w tym ceny surowców i nieruchomości ${ }^{62}$. Jest to przejawem trudnego do przecenienia, stymulującego wpływu Chin na koniunkturę w gospodarce światowej. D. Lampton, oceniając amerykański stosunek do chińskiej gospodarki, wskazał na charakterystyczną tendencję do wyolbrzymiania ich roli jako sprzedawcy i eksportera, przy niedocenianiu ich aktywności jako kupca, importera i inwestora ${ }^{63}$.

Istota roli Chin w międzynarodowym podziale pracy polega na specjalizacji w eksporcie towarów roboczochłonnych i imporcie towarów kapitałochłonnych. Jest to cecha gospodarek mniej rozwiniętych i nie zapewnia w dłuższej perspektywie utrzymania korzystnych terms of trade. Dlatego chcąc utrzymać pozycję mocarstwa gos-

58 Tamże, s. 59.

59 Tamże, s. 81.

60 Philip Segal, How Washington can be a hyper-power and a hyper-borrower: Foreign buyers of US bonds are banking on a stable US consumer market, "YaleGlobal", 2.09.2003.

61 Tamże, s. 82.

62 Special Report. China and the world economy, "The Economist", 3.07.2005, s. 67.

63 Por. David M. Lampton, The faces of Chinese power, "Foreign Affairs", I-II 2007. 
podarczego, muszą one dokładać starań, aby ich gospodarka zmierzała w kierunku bardziej zaawansowanego rozwoju gospodarczego: eksportera dóbr kapitałochłonnych lub indyjskiego modelu światowego back office ${ }^{64}$. Elementem chińskiego modelu wciąż pozostaje jednak pełnienie roli ,światowej fabryki”, wykorzystującej głównie przewagę w postaci taniej siły roboczej. Warto podkreślić, że pełnienie roli fabryki nie oznacza bycia jej właścicielem, ani dysponentem. Podnoszą się głosy, które kwestionują opinie o ogromnym znaczeniu chińskiej gospodarki ze względu na dysponowanie dużą jej częścią przez kapitał zagraniczny. Made in China niekoniecznie znaczy made by China, a raczej made by someone else ${ }^{65}$.

Godne pozazdroszczenia wskaźniki ekonomiczne nie mówią też całej prawdy o złożonych realiach tego kraju. Należy pamiętać, że Chinom wciąż pozostało wiele do zrobienia w kwestii reformowania gospodarki, optymalizowania zatrudnienia, podnoszenia wydajności pracy oraz poprawiania jakości życia i dobrobytu przeciętnych Chińczyków tak, aby największy rynek świata nie pozostawał tylko mrzonką, lecz zwiększał swoją chłonność. Mimo pokładanych w Chinach wielkich nadziei, pozostają one wciąż krajem dość biednym i stosunkowo zacofanym. Poza tanią siłą roboczą i bazą produkcyjną, nie mogą obecnie zaoferować wiele. W 2003 r. pod względem PKB per capita Chiny zajmowały odległe 129. miejsce, za Albanią i Ukraina, z kwotą 4,400 USD ${ }^{66}$. Znacznie wyższy on jest, rzecz jasna, kiedy wylicza się go według wskaźnika $\mathrm{PPP}^{67}$. Podobnie niegodnym pretendenta do miana mocarstwa jest wskaźnik ubóstwa $-10 \%$ oraz 104. miejsce w rankingu wskaźnika rozwoju społecznego (HDI), który z wartością 0,72 , plasował Chiny za Kirgistanem i Republiką Zielonego Przylądka ${ }^{68}$. Zdaniem R. Garnauta Chiny będą w stanie dorównać USA rozmiarem gospodarki w ciagu jednego pokolenia, lecz doścignięcie średniego amerykańskiego poziomu życia z pewnością zajmie im jeszcze jedno pokolenie lub nawet dłużej ${ }^{69}$.

Mimo oczywistych słabości społeczeństwa i gospodarki chińskiej, mocarstwa Zachodu zdają się jednomyślnie i konsekwentnie uznawać specjalne znaczenie Chin. Niewątpliwie główną tego przyczyną jest fascynacja interesami w Państwie Środka i perspektywa czerpania korzyści z ogromnego, ale wciąż nie w pełni dostępnego

\footnotetext{
${ }^{64}$ Por. Gurcharan Das, The India model, "Foreign Affairs", VII-VIII 2006.

${ }_{65}$ Por. D. Barboza, Made in China labels don't tell whole story, "International Herald Tribune", 9.02.2005.

${ }^{66}$ Por. Human Development Report UNDP - http://hdr.undp.org/reports/global/2003/indicator/index.html

${ }^{67}$ Według Banku Światowego produkt narodowy brutto per capita, liczony wedle wskaźnika realnej siły nabywczej w 2006 r. wynosił 7740 dolarów międzynarodowych, co dawało Chinom 102. miejsce w świecie. Patrz: GNI per capita 2006, Atlas method and PPP, w: World Development Indicators database, World Bank, 14 September 2007. Redakcja.

${ }^{68}$ W raporcie za 2007/8 r. Chiny awansowały na 81 miejsce. Redakcja..

${ }^{69}$ Por. Ross Garnaut, The sustainability and some consequences of Chinese economic growth, "Australian Journal of International Affairs", $2005 \mathrm{nr}$ 4, s. 516.
} 
rynku chińskiego. Konsekwencją takiego podejścia było przyjęcie ChRL w $2001 \mathrm{r}$. do WTO oraz zaproszenie chińskiego prezydenta Hu Jintao w 2003 r. na spotkanie grupy G-8 jako „strony dialogu”. Charakterystyczne jest, że raczej nie podejmuje się ewidentnych działań mających na celu ograniczanie rozwoju gospodarczego Chin, lecz preferuje się postawę otwartą na współpracę i aktywne uczestniczenie w profitach zeń płynących.

\section{Pozycja militarna}

Atrybutem chińskiej mocarstwowości, budzącym duży niepokój wielu obserwatorów, jest pozycja militarna Chin. W opinii Z. J. Pietrasia na przełomie lat 80. i 90. występowała $\mathrm{w}$ tej sferze znaczna nierównowaga: Chiny miały względnie słabą pozycję $\mathrm{w}$ stosunku do supermocarstw i jednocześnie bardzo silną w porównaniu $\mathrm{z}$ z mniejszymi sąsiadami ${ }^{70}$. Wraz z zapoczątkowaniem chińskich reform, obronę narodową objęła tzw. czwarta modernizacja. Oznacza to, że wzmocnienie materialnych podstaw armii, przez poprawę stanu wyposażenia, uzbrojenia i kwalifikacji kadr, stało się jednym z priorytetów polityki państwa.

Najistotniejszym komponentem potencjału militarnego Chin są ich siły nuklearne. Od 1964 r. Chiny stały się członkiem ekskluzywnego klubu jądrowego. Stopniowo wytworzyły trzeci arsenał nuklearny na świecie. Potencjał ten w stosunku do dwóch potentatów, USA i Rosji, jest bardzo mały. Według szacunków SIPRI Chiny posiadają zaledwie około 400 głowic nuklearnych ${ }^{71}$. Oznacza to w przybliżeniu 13 razy mniej głowic nuklearnych niż jest w dyspozycji tych dwu potęg ${ }^{72}$. Pod względem środków przenoszenia, ustępują one obu krajom około trzykrotnie. Arsenał nie tylko pod względem ilościowym, ale i jakościowym, jest bardzo ograniczony. Chiny nie dysponują m.in. pociskami wielogłowicowymi, nowoczesnymi atomowymi łodziami podwodnymi ani ruchomymi wyrzutniami pocisków międzykontynentalnych.

Chiny są obecnie w stanie dokonać pierwszego uderzenia strategicznego o ograniczonej skali, zaś możliwość przeprowadzenia odwetowego lub drugiego uderzenia jądrowego uznaje się za symboliczną. Jedynie na poziomie regionalnym posiadają zdolność drugiego lub odwetowego uderzenia ${ }^{73}$. Prawdopodobnie dysponują nie więcej niż 20 ładunkami strategicznymi mogącymi osiągnąć terytorium USA. Wartość odstraszania chińskiego potencjału atomowego jest bardzo ograniczona ${ }^{74}$.

\footnotetext{
${ }^{70}$ Z. J. Pietraś, Międzynarodowa rola Chin, cyt. wyd., s. 81.

${ }^{71}$ Por. "SIPRI Yearbook 2005", Sztokholm 2005, s. 318.

${ }^{72}$ Por. Ireneusz Topolski, Pozycja militarna ChRL, w: K. Iwańczuk, A. Ziętek (red.), Chiny w stosunkach ..., cyt. wyd., s.75.

73 Tamże, s. 75.

74 Por. Paul H.B. Godwin, China's nuclear forces: an assessment, „Current History”, IX 2000, s.260-265.
} 
Do niedawna podstawą tradycyjnej strategii nuklearnej było zapewnienie Chinom „minimum odstraszania”, a do tego celu nie potrzeba było dużego arsenału. Dotychczas sam fakt posiadania broni jądrowej i prestiż mocarstwa nuklearnego zdawał się wystarczać chińskiemu kierownictwu. Ostatnio pojawiła się w tym kraju koncepcja osiagnnięcia „ograniczonego odstraszania”, zapewniającego dysponowanie potencjałem, umożliwiającym nawiązanie walki. Taka zmiana może rodzić obawy potencjalnej rozbudowy chińskiego arsenału ${ }^{75}$.

Niewątpliwie najmocniejszą stroną chińskiej armii jest jej liczebność. Od wielu lat, mimo kilkukrotnych redukcji, utrzymuje ona pozycję największej armii świata. W 2006 r. liczyła 2,3 mln żołnierzy ${ }^{76}$. Jak podaje Biała Księga Obrony z 2006 r., z końcem 2005 r. dokonano redukcji wielkości sił zbrojnych o 200000 żołnierzy, co stanowi kontynuację cięć z 1985 r. (o $1 \mathrm{mln}$ ) i z 1997 r. (o 0,5 mln) 77 . Od lat 50. w sumie takich redukcji odbyło się dziewięć i zmniejszyły one armię o blisko 63\% (z pozio$\mathrm{mu} 6,2 \mathrm{mln}$ żołnierzy $)^{78}$. Świadczy to o odchodzeniu od postrzegania armii w kategoriach przede wszystkim ilościowych i zwiększaniu znaczenia czynnika jakościowego. Jest również przejawem odchodzenia od zimnowojennych napięć.

Wskaźnik określający liczbę żołnierzy na 1000 mieszkańców, czyli mówiący o poziomie zmilitaryzowania społeczeństwa, jest dla Chin bardzo niski. Wyniósł 2,1 w 1997 r. W analogicznym okresie dla USA był na poziomie 5,7, a dla Rosji nawet 8,8 . Dla Tajwanu był bardzo wysoki - aż 18,4 , natomiast w Japonii był nieco niższy niż w Chinach i wynosił $2^{79}$. Trudno więc byłoby uznać Chiny za kraj wysoce zmilitaryzowany.

Pozycja chińskich sił morskich jest wysoka i ustępują one jedynie USA oraz Rosji. Chiny mają jednak poważną konkurencję we flotach Japonii, Tajwanu i In$\mathrm{dii}^{80}$. Stopniowo flota ta jest modernizowana dzięki zakupom w Rosji oraz samodzielnym wysiłkom konstrukcyjnym ${ }^{81}$. Wciąż szczególnie słabą stroną jest brak zdolnego do działania lotniskowca ${ }^{82}$. Pozyskanie takiego mogłoby umożliwić Chinom prowadzenie działań zbrojnych na pełnym morzu, a tym samym godną mocarstwa zdolność do projekcji siły militarnej. Obecnie chińska marynarka wojenna

75 Tamże, s. 263-265.

${ }^{76}$ China's national defense in 2006, Information Office of the State Council of the PRC, XII 2006, s.11.

77 Tamże, s.11.

${ }^{78}$ China to maintain army of $2,3 \mathrm{mln}$, China.org.cn

${ }^{79}$ Por. I. Topolski, cyt. wyd. s. 78.

${ }^{80}$ Tamże, s. 81.

${ }^{81}$ Zalmay Khalilzad i inni, The United States and a rising China, RAND, 1999, rozdział III, s.50-57.

${ }^{82}$ Military power of PRC - 2007. Annual report to Congress, Departament Obrony Stanów Zjednoczonych, s. 32. 
jest w stanie prowadzić skuteczne działania ofensywne na pełnym morzu jedynie na ograniczoną skalę ${ }^{83}$.

Lotnictwo jest najsłabszym ogniwem w chińskim systemie wojskowym. Mimo pozyskiwania sprzętu od Rosji oraz realizacji własnych projektów, jego jakość i zdolność do działania jest bardzo ograniczona. Największą ułomnością jest brak lotnictwa strategicznego, nowoczesnych samolotów transportowych oraz samolotów walki elektronicznej. Zdolności operacyjne lotnictwa ograniczone są do zakresu regionalnego. Uznaje się, że siły zbrojne Chin są w stanie skutecznie prowadzić działania obronne, posiadają również możliwości przeprowadzenia działań przeciw innym państwom w regionie, lecz dysponują ograniczonymi zdolnościami operowania z dala od swoich baz. Tym samym ich zdolność do projekcji siły jest określana jako bardzo skromna lub ograniczona ${ }^{84}$.

Nowym wymiarem chińskiej pozycji militarnej lub raczej technologicznej, bo akcentowanie wojskowego charakteru wzbudziłoby być może w Chińczykach sprzeciw, są postępy w realizacji programu kosmicznego. Wraz z wystrzeleniem w $2003 \mathrm{r}$. pierwszego chińskiego załogowego statku kosmicznego Shenzhou V, Chiny dołaczyły do elitarnego klubu państw, posiadających zdolność wysyłania ludzi w kosmos. W 2005 r. misja została powtórzona, a kolejnym celem jest teraz lądowanie na Księżycu do $2020 \mathrm{r}^{85}$. W styczniu $2007 \mathrm{r}$. Chiny dokonały udanej próby rakietowego zniszczenia własnego satelity pogodowego, udowadniając tym samym zdolność atakowania obiektów satelitarnych na niskiej orbicie Ziemi.

Szczególny niepokój innych państw, a zwłaszcza dominującego supermocarstwaUSA, budzą rosnące chińskie wydatki militarne. Według szacunków SIPRI z 2005 r., pod tym względem Chiny zajmują 5. miejsce w świecie i mają 4\% udział w globalnych wydatkach na zbrojenia (przeznaczają na nie 41 mld USD). Na zbliżonym poziomie znajdują się Wielka Brytania, Francja i Japonia. Niedoścignionym liderem pozostają wciąż USA, które wydały ponad 478 mld USD i mają 45\% udział w wydatkach wojskowych w świecie. Oznacza to ponad 11 razy więcej niż Chiny. Nawet ujmując koszty zbrojeń według parytetu siły nabywczej (PPP), dzięki któremu Chiny awansowałyby na drugą pozycję, USA wydatkowałyby wtedy 2,5 raza więcej niż Chiny $^{86}$. Zgodnie z oficjalnymi informacjami strony chińskiej wydatki te były mniejsze i w 2005 r. wyniosły niewiele ponad 30 mld USD $^{87}$.

Mimo ogromu przewagi budżetu obronnego USA, jak też oczywiście wyższości technologicznej oraz utrzymującej się stosunkowo stałej proporcji chińskich wydat-

${ }^{83}$ Por. I. Topolski, cyt. wyd., s. 81.

${ }^{84}$ Bates Gill, Chinese military modernization and arms proliferation in the Asia-Pacific, w: Jonathan D. Pollack (red.), In China's shadow: Regional perspectives on Chinese foreign policy and military development, RAND Corporation, 1998, s. 22.

${ }^{85}$ China's space activities in 2006, Information Office of the State Council, 12.10.2006.

${ }^{86}$ Por. "SIPRI Yearbook 2006", Sztokholm 2006, s. 318.

87 China's national defence in 2006, Information Office of the State Council of the PRC, XII 2006, s. 31 . 
ków względem innych mocarstw, oskarżanie Chin o nadmierne zwiększanie tempa budowy potencjału militarnego jest dość często stosowanym narzędziem wywierania presji na rząd w Pekinie. Trzeba przyznać, że przyczynia się do tego również brak transparentności chińskich wydatków i kompatybilności ich wyliczeń ze światowymi standardami. W takiej sytuacji ustalenie rzeczywistego budżetu obronnego Chin nie jest prostym zadaniem i może prowadzić do bardzo różnych wyników, które dalej mogą być wykorzystywane w sposób instrumentalny. Porównanie szacunków chińskiego budżetu wojskowego, dokonane przez znane instytucje badawcze, ${ }^{88}$ pozwala wysnuć dwa podstawowe wnioski: a) nawet najbardziej skrajny szacunek SIPRI (wyrażony w PPP) będzie wciąż blisko 3 razy mniejszy niż budżet USA; b) chińskie wydatki wykazują łagodny trend wzrostowy w okresie ostatnich kilkunastu lat bez względu na źródło danych.

Wskaźnik udziału wydatków wojskowych w PKB w przypadku Chin także nie należy do wysokich: w końcu XX w. wynosił niewiele ponad $2 \%$, podczas gdy USA i Rosja notowały odpowiednio o 1 do 1,5 punkta procentowego więcej. Podobnie udział w budżecie państwa jest porównywalny do amerykańskiego $(17,6 \%$ do 16,3\% w Chinach w 1997 r.) i znacznie niższy od rosyjskiego (30,9\%). Przelicznik wydatków per capita ujawnia ogromną różnicę między Chinami i USA (61 do 1,030 USD) i Rosji (283 USD) ${ }^{89}$. Analitycy amerykańscy wskazują przede wszystkim na utrzymujący się trend wzrostowy wydatków, który wyprzedza tempo wzrostu gospodarki narodowej. Doroczny raport dla Kongresu USA na temat sił zbrojnych Chin podaje, że w okresie 1996-2006 średni wzrost wydatków wyniósł 11,8\%, zaś średni wzrost PKB wyniósł 9,2\% ${ }^{90}$. Chińska Biała Księga Obrony stoi na stanowisku, że w okresie 1990-2005 wzrost wydatków był na poziomie $9,64 \%{ }^{91}$, co odpowiada w przybliżeniu wzrostowi PKB (9,7\% według danych MFW). Trudno jednoznacznie zgodzić się zatem z alarmistycznym podejściem, mając na uwadze poziom zacofania chińskich sił zbrojnych, przy jednoczesnym akceptowaniu ważnej roli, jaką Chiny mają pełnić w świecie. Dualizm w podejściu jest zauważalny w najnowszym raporcie Departamentu Obrony USA, w którym Chiny z jednej strony to główna wschodząca potęga, mająca największe szanse konkurować militarnie z USA, a z drugiej - oczekuje się od Chin partnerstwa w zwalczaniu wspólnych wyzwań dla bezpieczeństwa ${ }^{92}$.

Znaczne trudności nastręczają próby oceny rzeczywistego charakteru chińskich strategii wojskowych. Kierunek ich zmian w ostatnich latach zdaje się zmierzać ku zwiększeniu asertywności i aktywności, głównie za sprawą nowej strategii „ograni-

\footnotetext{
${ }^{88}$ Military power of PRC - 2007. Annual report to Congress, Departament Obrony USA, s. 34.

89 Por. I. Topolski, cyt. wyd., s. 86.

90 Military power of PRC - 2007..., cyt. wyd., s. 33.

91 China's national defence in $2006 \ldots$, s. 31.

92 Quadrennial defence review report - 2006, Departament Obrony USA, II 2006, s. 29.
} 
czonego odstraszania"93 $\mathrm{w}$ aspekcie nuklearnym oraz wychodzenie poza obronę wybrzeża na szersze obszary morskie, które zaczyna traktować się jako część własnego terytorium ${ }^{94}$.

W chińskiej doktrynie wojennej warto wskazać na dwa przełomy: połowa lat 80 . to porzucenie doktryny wojny totalnej na rzecz wojny lokalnej oraz początek lat 90. - zmodyfikowanie strategii wojny lokalnej na „wojnę w warunkach zaawansowanych technologii”. Świadczy to o dwóch tendencjach: o budowaniu nowoczesnej armii, mniejszej liczebnie, ale o wyższej zdolności obronnej, oraz o dostosowaniu armii do wymogów nowoczesnego pola walki.

Według E. Haliżaka celem modernizacji chińskiego potencjału militarnego jest, po pierwsze, stworzenie armii zapewniającej status mocarstwowy oraz, po drugie, zapewnienie zdolności do reagowania na wypadek kryzysu w Cieśninie Tajwańskiej ${ }^{95}$.

\section{Pozycja polityczna}

Katalizatorem już uzyskanej i umacniającej się mocarstwowości Chin jest czynnik polityczny. Za jego sprawą, choć pozbawione solidnych podstaw gospodarczych i militarnych, zdobyły one bardzo istotną pozycję nie tylko w regionie, ale i w świecie.

Najważniejszym przejawem politycznego znaczenia Chin jest posiadanie statusu stałego członka Rady Bezpieczeństwa ONZ. W czasie II wojny światowej Amerykanie uznawali Chiny, podówczas rządzone przez Guomindang Chiang Kai-sheka (Jiang Jieshi), za „kraj obiecujący”96 i zdolny pełnić mocarstwową rolę w powojennym świecie. Na konferencji w Kairze w listopadzie 1943 r. Chiang Kai-shek był traktowany przez aliantów jako jeden z ,wielkiej czwórki”, a Chinom przyznano status „mocarstwa sojuszniczego”. Ze względu na przegraną przez Guomindang wojnę domową i ucieczkę Chianga na Tajwan, przez ponad 20 lat przywilej reprezentowania całych Chin posiadał rząd Republiki Chińskiej, rezydujący na Tajwanie (gdyż Stany Zjednoczone i większość państw zachodnich nie uznawała ChRL). Nawiązanie współpracy Waszyngtonu z Pekinem, co otwarło drogę do odzyskania w $1971 \mathrm{r}$. miejsca w ONZ przez Chiny kontynentalne ${ }^{97}$, należy uznać za początek odzyskiwania pozycji mocarstwowej. Trzeba zarazem podkreślić, że bez zjednoczenia Chin z Tajwanem, który przez ogromną większość państw traktowany jest jako część te-

93 Paul H.B. Godwin, China's nuclear forces: an assessment, „Current History”, IX 2000, s. 263.

${ }^{94}$ Por. Samuel S. Kim, China as a great power, „Current History”, IX 1997.

${ }^{95}$ E. Haliżak, Zmiana uktadu sit USA-Chiny..., cyt. wyd., s. 94.

${ }_{96}$ John K. Fairbank, Historia Chin-Nowe spojrzenie, Dom Wydawniczy Bellona, Warszawa 2003, s. 303 .

${ }_{97}$ Por. Zhong Huaiwen, Years of trial, turmoil and triumph - China from 1949 to 1988, Foreign Language Press, Beijing 1989, s. 156-157. 
rytorium chińskiego, uzyskanie przez Chiny pełnego statusu mocarstwa globalnego nie będzie jednak możliwe ${ }^{98}$.

Status stałego członka Rady Bezpieczeństwa jest atrybutem nie do przecenienia. Nie tylko daje posiadaczowi prawo decydowania o kluczowych sprawach świata, wyposażając dany rząd w potężne narzędzie w postaci prawa weta, lecz sam przez się potwierdza mocarstwową rangę państwa, a także zobowiązuje pozostałych uczestników wspólnoty międzynarodowej do uznawania jej i liczenia się z jej zdaniem. Tak oto Chiny nie musiałyby nawet być potęgą gospodarczą czy militarną, aby być mocarstwem w wymiarze politycznym. Uzyskały taką pozycję niejako w prezencie - w wyniku nie najtrafniejszych kalkulacji amerykańskich, jak powinien wyglądać powojenny porządek międzynarodowy. Ponadto pozycji tej nie można w zasadzie stracić - z grona stałych członków Rady Bezpieczeństwa można być wykluczonym tylko na własne życzenie, gdyż stabilności tego elitarnego grona broni prawo weta. Podobnie przywilej wpływania na to, które państwa można by ewentualnie dopuścić do tego gremium, jest skutecznym narzędziem kształtowania międzynarodowej rzeczywistości. Jak udowadnia historia ONZ, żadne państwo nie wykluczyło się samo z Rady Bezpieczeństwa, a reforma instytucjonalna, zakładająca dokooptowanie nowych stałych członków, wciąż nie nastąpiła. Dlatego w przewidywalnej przyszłości Chiny nie utracą pozycji mocarstwa, a przywilej weta mogą stosować jako argument w sporach z rywalami - blokując np. przyjęcie Japonii do grona stałych członków Rady.

Wraz z zapoczątkowaniem procesu otwarcia na świat, Chiny rozpoczęly proces integracji ze światem oraz zwiększania swojej obecności we wspólnocie międzynarodowej ${ }^{99}$. Głównym przejawem tego procesu jest uczestnictwo Chin w organizacjach międzynarodowych oraz w operacjach pokojowych pod egidą ONZ. Udział Chin w składkach ONZ wzrósł z 0,9\% w 1998 r. do $2,05 \%$ od 2004 r. ${ }^{100}$

Chińskie zaangażowanie międzynarodowe postępowało w imponującym tempie i są one dzisiaj obecne w niemal wszystkich ważniejszych organizacjach i forach ${ }^{101}$. Chiny nie są co prawda członkiem grupy państw najbardziej uprzemysłowionych G-8, lecz uczestniczą od 2005 r. wraz z innymi czterema wschodzącymi gospodar$\mathrm{kami}^{102} \mathrm{w}$ jej spotkaniach (w ramach mechanizmu G-8+5). Mimo iż chińska gospodarka posiada większe znaczenie niż włoska, kanadyjska czy francuska, wciąż pozostają one formalnie poza tym elitarnym gronem. Z jednej strony ten „klub bogatych” nie kwapi się do zaproszenia Chin do swego grona, z drugiej zaś nie zabiegają chyba o to same Chiny. Wolą one być traktowane jako „biedny kraj rozwijający się”, co

98 Por. Shelley Rigger, Taiwan: Finding opportunity in crisis, "Current History”, IX 1999.

99 Por. Evan S. Medeiros, M. Taylor Fravel, China's new diplomacy, „Foreign Affairs”, XI-XII 2003.

100 Zob.: http://www.globalpolicy.org/finance/assessmt/dues2004.pdf

101 Justin S. Hempson-Jones, The evolution of China's engagement with international governmental organizations. Toward a liberal foreign policy?, "Asian Survey”, 2006 nr 5, s. 702-720.

102 Indie, Brazylia, Meksyk i RPA. 
daje im rozmaite przywileje gospodarcze ${ }^{103}$. Stąd ograniczone uczestnictwo w tym forum wydaje się wygodne dla obu stron, gdyż strona chińska może pełnić rolę ,pomostu między Północą a Południem" "104. W opinii E. Haliżaka Chiny pragną jednak możliwie szybko dołączyć do G-8, gdyż byłoby to legitymizacją chińskiej pozycji mocarstwa ekonomicznego, nie spełniają jednak wymogów gospodarczych i liberalizacji systemu finansowego ${ }^{105}$.

Należy podkreślić, że podejście Chin do organizacji międzynarodowych stało się coraz bardziej twórcze. Z inicjatywy Chin powstało szereg organizacji międzynarodowych i for, służących nie tylko pogłębianiu współpracy, ale promowaniu i rozbudowywaniu chińskich wpływów. Do tego rodzaju instytucji można zaliczyć m.in. Szanghajską Organizację Współpracy (SCO - powstałą w 2005 r.), Forum Współpracy Chiny-Afryka (CACF - 2000 r.), Chińsko-Arabskie Forum Współpracy (2004), Forum Azjatyckie Boao (2001). Szczególne znaczenie pod tym względem może uzyskać koncepcja budowy Wspólnoty Wschodnio-Azjatyckiej (East Asia Community) w oparciu o zwołany po raz pierwszy w 2005 r. szczyt państw Azji Wschodniej ${ }^{106}$. Charakterystyczne dla tej koncepcji jest wzmocnienie tradycyjnych więzi państw regionu i łączących je powiązań gospodarczych, przy jednoczesnym ograniczeniu wpływów USA, które pozostały poza obrębem ugrupowania (głównym forum basenu Pacyfiku pozostaje jednak wciąż APEC, łączący państwa z obu jego brzegów). Zdaniem niektórych, ta nowa koncepcja może służyć rugowaniu amerykańskiej obecności w regionie $^{107}$. Według E. Haliżaka taka struktura jest doskonała okazja dla wykorzystania jej przez Chiny jako legitymizacja (...) państwa w regionie i świecie ${ }^{108}$.

$\mathrm{W}$ analizie atrybutu politycznego chińskiej mocarstwowości należy uwzględnić fakt występowania Chin jako pewnego rodzaju alternatywy dla przyjmowanych dotychczas modeli polityczno-gospodarczych. Sztandarowym chińskim produktem w tym aspekcie jest „,pekiński consensus” - pojęcie ukute przez J.C. Ramo, jako określenie antytezy „waszyngtońskiego consensusu”, czyli nowej i skutecznej, bo sprawdzonej w praktyce, recepty na rozwój, uwzględniający specyfikę każdego kraju bez narzucania dyktatu modelu liberalnego ${ }^{109}$. Za pośrednictwem takich wzorców Chiny starają się być obecne w regionach globu, o których świat zdawał się już zapominać. Afryka i Ameryka Łacińska stają się dla Chin regionem nasilonej aktywności, głównie z przyczyny strategicznej pogoni za dostępem do źródeł surowców i nowych rynków

${ }^{103}$ Jeffrey E. Garten, China: The missing member at the G-8 Table, YaleGlobal, VI 2004.

${ }^{104}$ G-8 will add to China's global profile, "People's Daily", 11.06.2007.

105 E. Haliżak, Zmiana układu sit USA-Chiny..., cyt. wyd., s. 86.

106 Por. E. Haliżak, Wspólnota Pacyfiku a Wspólnota Wschodnioazjatycka, „Żurawia Papers”, Zeszyt nr 8, 2006, s. 134-140.

107 Por. S. Harris, cyt. wyd., s. 485.

108 E. Haliżak, Wspólnota Pacyfiku..., cyt. wyd., s. 143,

109 Por. Bates Gill, Yanzhong Huang, Sources and limits of Chinese 'soft power', "Survival”, 2006 nr 2, s. 20. 
zbytu. Chiny bezsprzecznie umieją wykorzystywać procesy globalizacji do własnego rozwoju i umacniania swej pozycji w świecie.

\section{Uwagi końcowe}

Upolitycznienie dyskursu na temat potęgi Chin powoduje, że wśród badaczy nie ma zgody, co do oceny ich rzeczywistego znaczenia i pozycji. Zbyt wiele opinii zależy od nastawienia i przekonań poszczególnych autorów. Chiny określa się między innymi mianem „śpiącego smoka”, „kandydata na supermocarstwo”, „supermocarstwa”"110, „potęgi drugiej klasy”, „,mocarstwa na skalę regionalną”"11, „słabej i wciąż wschodzącej potęgi" ${ }^{112}$ oraz ,średniego mocarstwa" ${ }^{113}$. Stosunkowo wyważoną opinię prezentuje Z. Brzeziński w książce Wielka szachownica. Zakładając dalszy wzrost Chin, pozostaje na stanowisku, że $w 2020 \mathrm{r}$. Chiny nawet w najbardziej sprzyjajacych okolicznościach prawdopodobnie nie stanq się autentycznym - a zatem konkurencyjnym w kluczowych dziedzinach - mocarstwem światowym. Mimo to kraj ten jest na dobrej drodze, aby stać się czołowym mocarstwem regionalnym Azji Wschodniej ${ }^{114}$. Dobranie odpowiednich metod traktowania rosnących w siłę Chin wydaje się kwestią zasadniczą. Niewłaściwe podejście mogłoby bowiem skierować Chiny na drogę jednego z mniej korzystnych spośród alternatywnych scenariuszy: Chin chaosu, Chin wspótdziałajacych lub Chin asertywnych ${ }^{115}$.

Syntetyczny przegląd podstawowych atrybutów międzynarodowej pozycji Chin upoważnia jednak do stwierdzenia, że Chiny są już mocarstwem. Szczegółowa analiza poszczególnych atrybutów wskazuje na zajmowanie wysokiego miejsca względem innych uczestników stosunków międzynarodowych, we wszystkich głównych aspektach mocarstwowości. Uzasadnia to zaliczenie Chin do wąskiego grona autentycznych mocarstw. Poszczególne wymiary, poddane krytycznej ocenie, wykazują jednak szereg potencjalnych ułomności i zagrożeń.

Chiny pod względem pozycji demograficznej zasługują na miano absolutnego światowego lidera. Jednak wielkość oraz jakościowe i strukturalne słabości tego kraju pod tym względem wskazują na istnienie poważnych obciążeń dla dalszego zrównoważonego rozwoju oraz stwarzają potencjalne ryzyko negatywnego wpływu nie tylko na pozycję Chin, ale i realnego zagrożenia dla świata. Pod względem gospodarczym, za sprawą potężnych zasobów siły roboczej, liczebność ludności jest jed-

\footnotetext{
110 Por. Samuel S. Kim, cyt. wyd.

111 Michael Yahuda, China's search for a global role, „Current History”, IX 1999, s. 267.

112 Michael D. Swaine, Does China have a grand strategy?, „Current History”, IX 2000, s. 275.

113 Gerald Segal, Does China matter?, „Foreign Affairs”, IX/X 1999.

114 Zbigniew Brzeziński, Wielka szachownica, Warszawa: „Świat Książki” 1998, s. 206.

115 M. D. Swaine, cyt. wyd., s. 278.
} 
nak źródłem przewagi nad wieloma z konkurentów. Można uznać, że jest to atrybut godny mocarstwa, ale należącego wciąż do trzeciego świata.

W aspekcie terytorialnym Chiny należą do ścisłej czołówki. Jednak jego terytorium, z przyczyn geograficznych i ludnościowych, nie jest najlepiej wykorzystywane. Geopolityczna pozycja jest dogodna i faworyzująca Chiny, głównie za sprawą ich położenia w obszarze Azji i Pacyfiku, centralnej lokalizacji w Azji Wschodniej, w zasięgu głównych szlaków handlu morskiego oraz w sąsiedztwie prężnych gospodarek azjatyckich. Jako państwo lądowe Chiny wykorzystują bliskość zasobów energetycznych Azji Centralnej i Syberii, a także dążą do pełnienia roli państwa tranzytowego. Zasługują na miano mocarstwa zarówno według Mackindera, jak i Spykmana.

Pod względem pozycji gospodarczej Chiny należą do ścisłej czołówki, jako 4. lub 2. gospodarka, zależnie od ujęcia w cenach stałych lub PPP. W handlu zagranicznym są 3. potęga, a w wymiarze rezerw walutowych niedoścignionym liderem. Posiadają wymierny wpływ na światową koniunkturę, ceny towarów i surowców. Będąc głównym odbiorcą FDI, zaczynają pełnić rolę eksportera kapitału, a nawet poważnego wierzyciela USA. W ujęciu tempa rozwoju są gospodarką o imponującej stabilności wieloletniego i wysokiego tempa wzrostu - średnio ok. 10\% rocznie od ponad ćwierćwiecza. Gospodarka ich posiada wprawdzie bardzo istotne wady i ułomności strukturalne, lecz prawdopodobieństwo spełnienia się scenariusza drastycznego spowolnienia lub nawet gwałtownego załamania się rozwoju gospodarczego nie wydaje się wysokie. Pozycja gospodarcza Chin jest chyba obecnie najmocniejszym atrybutem ich mocarstwowości. Przejawy chińskiej potęgi gospodarczej - „fabryki świata” - codziennie spotykamy w naszych domach, nawet o tym nie wiedząc.

Aspekt militarny także, co najmniej z dwóch powodów, uzasadnia zaliczenie Chin do grona mocarstw. $Z$ jednej strony dysponują największą armia, z drugiej zaś przynależą do elity mocarstw nuklearnych i dysponujących technologiami kosmicznymi. Wysoki poziom wydatków wojskowych na potrzeby owej najliczniejszej i wciąż słabo wyposażonej armii nie powinien być szczególnie alarmujący, zwłaszcza w porównaniu z dziesięciokrotnie większymi wydatkami USA. Armia chińska wciąż się modernizuje, ale albo skala zapóźnień jest tak wielka, albo tempo dozbrajania zbyt niskie, bowiem wciąż posiada ona ograniczone zdolności projekcji siły. Chiny należy uznać zatem za mocarstwo militarne, ale długo jeszcze nie staną się większym militarnym zagrożeniem dla świata.

W wymiarze politycznym mocarstwowość Chin nie powinna podlegać dyskusji. Jej niewzruszalną gwarancją jest status stałego członka Rady Bezpieczeństwa ONZ. Dzięki szerokiemu uczestnictwu w organizacjach międzynarodowych i forach, Chiny zaznaczają swoją obecność w wielu sprawach o znaczeniu globalnym i regionalnym. Przez koncepcje „pokojowego rozwoju” swojego kraju i „harmonijnego świata” starają się zwiększać znaczenie swojej własnej soft power. Nasilając obecność w re- 
gionach zaniedbywanych przez pozostałe mocarstwa, promują „pekiński consensus”, jako alternatywę rozwojowa. Z $\mathrm{Z}$ powodzeniem podejmują rywalizację z Rosją i USA o wpływy w Azji Centralnej. Największą uwagę koncentrują na własnym regionie Azji, a zwłaszcza Azji Wschodniej - w której we współpracy z państwami ASEAN, Japonią i Republiką Korei zmierzają ku stworzeniu podstaw Wspólnoty Wschodnioazjatyckiej, opartej na konfucjańskich korzeniach. W wymiarze politycznym Chiny bez wątpienia są coraz aktywniejszym mocarstwem regionalnym, ale o światowych aspiracjach i rosnącej roli globalnej.

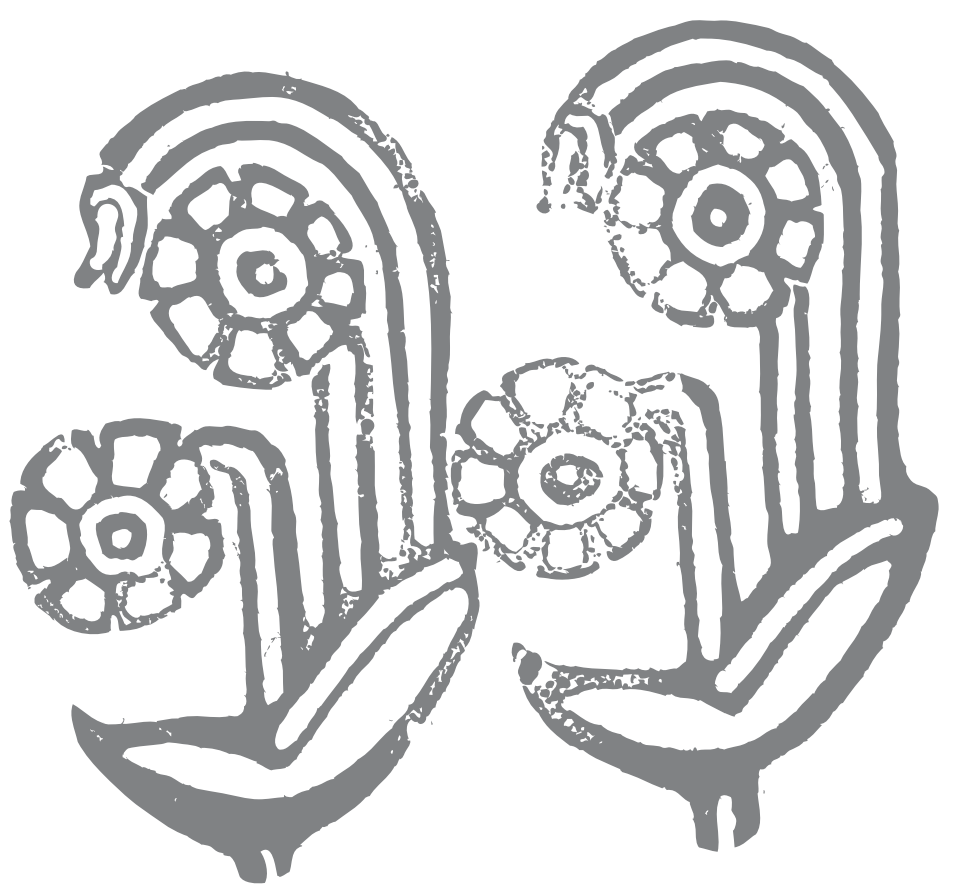

